\title{
Electricity Demand, GDP and Employment: Evidence from Shandong
}

\author{
Bing $\mathrm{Li}^{1 *}$, Zhiwei Zhang ${ }^{2}$ \\ ${ }^{1}$ School of International Economics and Trade, Shandong University of Finance and Economics, Jinan, Shandong, 250014, P.R. China \\ ${ }^{2}$ Department of Public Relations, State Grid Shandong Electric Power Company, Jinan, Shandong, 250001, P. R. China
}

\begin{abstract}
This paper analyses the possible relationship among the electricity demand, GDP and employment in Shandong. The cointegration equation coefficients show that there is a positive correlation among electricity demand, GDP and employment. Granger causality test indicates that there is a one-way Granger causal relationship both from electricity demand to GDP and from electricity demand to employment. Since that Shandong GDP growth can be explained by the increased electricity demand and the increased number of people employed, policies encouraging electricity demand and employment can be issued to help push further economic development in Shandong province.
\end{abstract}

\section{Introduction}

Shandong electricity demand reached 591.68 billion $\mathrm{kw} / \mathrm{hr}$ in 2018 with the annual increasing rate at 7 per cent. At the same time, Shandong is developing very fast in its Gross Domestic Product (GDP). The annual growth rate of Shandong GDP is 5 per cent in 2018. We want to know whether the development of GDP will help boost the increasing electricity demand or the vice versa. This is actually a very important relationship because if the result is that GDP helps boost the electricity demand, then policies should be studied to help increase economic development, as long as the economic develops, then private investment will follow the market forces and go to the electricity market to the development of the infrastructure such as power plant building and grid construction. But if the result is that electricity demand helps boost the GDP, then the policies will be focused on building the infrastructure in electricity market and as long as the electricity market develops, the GDP will go up accordingly. At the same time, the employment is a big influencing factor in the electricity market and GDP growth because theories indicate that employment usually will go hand in hand with electricity demand and GDP growth.

\section{Literature Review}

Many researches applied time series methodologies to examine the causal relationship among electricity demand, real per capita GDP and total labor force in some specific countries such as Italy. The equilibrium relation implied that, in the long-run, GDP and labor force were correlated negatively, as well as GDP and electricity. Studies show that there was a bi-directional Granger causality flow between real per capita GDP and electricity demand, and that labour forces Granger-cause neither real per capita GDP nor electricity demand [1]. Some other researches concerned about policies with the goals of reducing energy demand and encouraging the use of more efficient energy technologies. Policies will have an effect on the cost of energy; a quantitative examination of the energy demand is warranted. So some research papers focused on the likely effects of increased electricity prices on the demand for electricity [2].

Some research papers based on transaction at power generation side analysed in depth, and a supervised price based differential contact was proposed and the electricity demand elasticity is introduced into bidding based market. And the analysis and discussion on supervised price based differential contact were analysed and discussed in the field of economic meaning [3]. In a way, economic growth and appliance saturation are increasing electricity consumption as some studies indicated in Mexico [4].

While some other research made studies on the determinants of household electricity consumption in the Czech Republic. The endogenous variable (electricity consumption in households) is explained by using a set of seven independent explanatory variables [5]. While the electricity is one of the energy types that have attracted a lot of interest due to its versatility. Rigorous analysis of the determinants of electricity demand as well as its accurate forecasting are of vital importance in the design of an effective energy policy to deal with current and future electricity needs. Several forecasting models have been used in electric power systems for achieving accuracy. Most studies have focused on the relationship between electricity demand and economic parameters

*Corresponding author e-mail: libingchina@sina.com 
such as gross domestic product (GDP), Gross National Product (GNP), national income, and the rate of employment as well as unemployment [6][7].

In this paper, after the econometric methodology and data are briefly explained, we will do unit root test, cointegration test and Granger causality test to estimate the possible relationship among the electricity demand, GDP and employment in Shandong.

\section{Econometric methodology and data}

VAR model can be used in the analysis of long run relationship of variables. Here the equation of one lag is written as follows:

$$
Y_{t}=\alpha+\Phi Y_{t-1}+\varepsilon_{t}, \varepsilon_{t} \sim \operatorname{IID}(0, \Omega)
$$

This model can be stated in a Vector Moving Average (VMA) form as:

$$
Y_{t}=(I-\Phi)^{-1} \alpha+\sum_{i=0}^{\infty} \Phi{ }^{i} \varepsilon_{t-i}
$$

It could be stated in the following matrix form:

$$
\left(\begin{array}{l}
x_{t} \\
y_{t}
\end{array}\right)=\left(\begin{array}{cc}
1-\phi_{22} & \phi_{12} \\
\phi_{21} & 1-\phi_{11}
\end{array}\right)\left(\begin{array}{l}
\alpha_{1} \\
\alpha_{2}
\end{array}\right)+\sum_{i=0}^{\infty}\left(\begin{array}{ll}
\varphi_{11}(i) & \varphi_{12}(i) \\
\varphi_{21}(i) & \varphi_{22}(i)
\end{array}\right)\left(\begin{array}{l}
\varepsilon_{x t-i} \\
\varepsilon_{y t-1}
\end{array}\right)
$$

Granger causality test is used in this paper to test the relationship of Electricity demand and the GDP. This test idea was put forward by J. Granger in 1969 and then developed by Henry and Richard in 1970s. The Granger causality test is using the following two equations to do the test:

$$
\begin{aligned}
& \mathrm{y}_{\mathrm{t}}=\sum_{\mathrm{i}-1}^{\mathrm{q}} \mathrm{a}_{\mathrm{i}} \mathrm{x}_{\mathrm{t}-\mathrm{i}}+\sum_{\mathrm{j}-1}^{\mathrm{q}} \beta_{\mathrm{j}} \mathrm{y}_{\mathrm{t}-\mathrm{j}}+\mathrm{u}_{1 \mathrm{t}} \\
& \mathrm{x}_{\mathrm{t}}=\sum_{\mathrm{i}-1}^{\mathrm{s}} \lambda_{\mathrm{i}} \mathrm{x}_{\mathrm{t}-\mathrm{i}}+\sum_{\mathrm{j}-1}^{\mathrm{s}} \delta_{\mathrm{j}} \mathrm{y}_{\mathrm{t}-\mathrm{j}}+\mathrm{u}_{2 \mathrm{t}}
\end{aligned}
$$

The stationarity of the variable series is important in the Granger causality test. This is because the nonstationary sequences might lead to a false causal relationship. In the stationarity test, if the sequence is found not stationary, it shall be differenced one or more times to become stationary, and only then the Granger test can be done accordingly. Usually a difference stationary series is said to be integrated and is denoted as
I(d) where $d$ is the order of integration. The order of integration is the number of unit roots contained in the series, or the number of differencing operations it takes to make the series stationary. For the random walk, there is one unit root, so it is an I(1) series. Similarly, a stationary series is I(0). Standard inference procedures do not apply to regressions which contain an integrated dependent variable or integrated regressors. Therefore, it is important to check whether a series is stationary or not before using it in a regression.

All the variables analysed in this paper have been expressed in a logarithmic scale. The empirical study uses time-series data for electricity demand (LNEED), GDP (LNGDP) and number of the people employed as labor force (LNEEP) for the 1995 - 2018 periods in Shandong province, P. R. China. Data are obtained from the Shandong Statistical Yearbook annul edition. In this paper electricity demand is expressed in terms of $\mathrm{GW} / \mathrm{h}$, GDP in constant RMB, and the number of the people employed in 10,000 persons. The choice of the starting period is constrained by data availability on electricity demand. The Eviews 9.0 is used as the software for analysis.

\section{Tests results and discussion}

\subsection{Unit root test}

We use Group unit root test to check the variables are stationary or not. Automatic selection of maximum lags is used in the test and the automatic lag length selection based on SIC: 0 by the Newey-West automatic bandwidth selection and Bartlett kernel method. First, the variables are tested in level as listed in Table 1. The Null hypothesis is that we assume a common unit root process. The Levin, Lin \& Chu Test shows that the probability is 0.0172 which is more than the 0.01 significance. So the three variables do have common unit root and they are not stationary. The next null hypothesis is to assume individual unit root for those variables and Im Pesaran and Shin W-stat, ADF, PP statistics show that the variables have individual unit root and they are not stationary, either.

Table 1. Group Unit Root Test Results for $\mathrm{LN}^{* * *}$ in Level

\begin{tabular}{lcc}
\hline Group unit root test: Summary Series: LNEED, LNGDP, LNEEP in level & \\
\hline Method & Statistic & Prob.** \\
Null: Unit root (assumes common unit root process) & & \\
\hline Levin, Lin \& Chu t* & -2.11575 & 0.0172 \\
\hline Null: Unit root (assumes individual unit root process) & & \\
\hline Im, Pesaran and Shin W-stat & -0.16841 & 0.4331 \\
ADF - Fisher Chi-square & 4.68484 & 0.5848 \\
PP - Fisher Chi-square & 3.36390 & 0.7620 \\
\hline ** Probabilities for Fisher tests are computed using an asymptotic Chi & \\
$\quad$-square distribution. All other tests assume asymptotic normality. & \\
\hline
\end{tabular}

We then take the $1^{\text {st }}$ difference of the variables to test their stationarity. Table 2 shows the results following the same methods as in we have in the level scale. From the Levin, Lin \& Chu statistics, the probability is 0.001 which is less than that of 1 per cent significance, so it is stationary. And the Im, Pesaran and Shi W-stat, ADFFisher Chi-square, PP-Fisher Chi-square statistics 
probability all show that the variable in 1st difference do

not have unit root and they are stationary.

Table 2. Group Unit Root Test Results for $\mathrm{LN}^{* * *}$ in $1^{\text {st }}$ Difference

\begin{tabular}{lcc}
\hline Group unit root test: Summary Series: LNEED, LNGDP, LNEEP in $1^{\text {st }}$ Difference & \\
\hline Method & Statistic & Prob.** \\
Null: Unit root (assumes common unit root process) & & \\
\hline Levin, Lin \& Chu t* & -3.71844 & 0.0001 \\
\hline Null: Unit root (assumes individual unit root process) & & \\
\hline Im, Pesaran and Shin W-stat & -3.39453 & 0.0003 \\
ADF - Fisher Chi-square & 37.4323 & 0.0000 \\
PP - Fisher Chi-square & 239.984 & 0.0000 \\
** Probabilities for Fisher tests are computed using an asymptotic Chi & \\
$\quad$-square distribution. All other tests assume asymptotic normality. & \\
\hline
\end{tabular}

\subsection{Cointegration test}

From the above analysis, we know that each variable of LNEEC LNGDP LNEEP meets the I(1) first-order stationary conditions. In this section, we will use the cointegration method which is based on the VAR model proposed by Johansen $(1988,1991)$ and Johansen and Juselius (1990) to test the possible long-run relationship that may exist among variables. We use the Trace statistics test in the cointegration test and the linear deterministic trend is adopted in the Trend assumption. The lags interval is each variable's first differences are chosen from 1 to 1 . So the unrestricted cointegration rank test (Trace) shows that there is 1 conintegration equation exiting at the 0.05 level as shown in table 4 .

Table3 VAR model variables cointegration test

\begin{tabular}{|c|c|c|c|c|}
\hline \multicolumn{5}{|c|}{$\begin{array}{l}\text { Included observations: } 22 \text { after adjustments } \\
\text { Trend assumption: Linear deterministic trend } \\
\text { Series: LNEED LNGDP LNEEP } \\
\text { Lags interval (in first differences): } 1 \text { to } 1 \\
\text { Unrestricted Cointegration Rank Test (Trace) } \\
\end{array}$} \\
\hline $\begin{array}{l}\text { Hypothesized } \\
\text { No. of CE(s) }\end{array}$ & Eigenvalue & $\begin{array}{c}\text { Trace } \\
\text { Statistic }\end{array}$ & $\begin{array}{c}0.05 \\
\text { Critical Value }\end{array}$ & Prob.** \\
\hline None $*$ & 0.743201 & 40.70582 & 29.79707 & 0.0019 \\
\hline At most 1 & 0.283382 & 10.79764 & 15.49471 & 0.2242 \\
\hline At most 2 & 0.145800 & 3.466970 & 3.841466 & 0.0626 \\
\hline
\end{tabular}

The coefficients of VAR model are estimated on EViews 9.0 software with a lag number $p=1$ as shown in Equation (6). From this equation, we can say that if there is 1 per cent change of LNGDP in lag order 1, there is a 0.005 per cent change in LNEED. And that if there is a 1 per cent change in LNEEP in lag order 1 , there is a 0.72 per cent change in LNEED.

$$
\begin{aligned}
& \text { LNEED }=0.87 * \operatorname{LNEED}(-1)+0.005 * \operatorname{LNGDP}(-1) \\
& +0.72 * \operatorname{LNEEP}(-1)-5.15
\end{aligned}
$$

\subsection{Granger Causality Tests and other residual tests}

At lagging order 3 and 10\% significant level, Table 4 indicates that LNGDP does not Granger cause LNEED, but LNEED does Granger cause LNGDP. This means that GDP growth can be explained by the electricity demand increase but electricity demand increase could not be explained by the GDP growth. This is only a oneway Granger cause from LNEED to LNGDP. As to LNEEP and LNEED, we can see from table 4 that LNEEP does not Granger cause LNEED, but LNEED does Granger cause LNEEP. This means that increased number of employed people could be explained by the electricity demand, but electricity demand increased could not be explained by the increased number of employed people. This is also a one-way Granger causal relationship. As to third group LNEEP and LNGDP, we can see from the results that there is a two-way Granger causal relationship existing. That is, LNEEP Granger causes LNGDP and LNGDP Granger causes LNEEP. This means that GDP growth and increased number of employed people could be explained with each other. 
Sample: 19952018

Table 4 Pairwise Granger causality tests

\begin{tabular}{lcccr}
\hline \hline Null Hypothesis: & Obs & F-Statistic & Prob. & Conclusion \\
\hline \hline LNGDP does not Granger Cause LNEED & 21 & 0.19782 & 0.8961 & Accept \\
LNEED does not Granger Cause LNGDP & & 8.08410 & 0.0023 & Reject \\
\hline \hline LNEEP does not Granger Cause LNEED & 21 & 0.57521 & 0.6407 & Accept \\
LNEED does not Granger Cause LNEEP & & 3.95809 & 0.0309 & Reject \\
\hline \hline LNEEP does not Granger Cause LNGDP & 21 & 7.87727 & 0.0025 & Reject \\
LNGDP does not Granger Cause LNEEP & & 2.73264 & 0.0833 & Reject \\
\hline \hline
\end{tabular}

As regards the robustness of the VAR model, for all the equations, a Lagrange-multiplier (LM) test for autocorrelation in the residuals of VAR clarifies at the 5\% significance level, the null hypothesis cannot be rejected that there is no serial correlation in the residuals for the orders 1, 2, .. 5 tested. Using the Portmanteau autocorrelation test, the Box-Pierce and Ljung-Box Qstatistics show that the null hypothesis of no serial correlation up to lag 12 cannot be rejected. Checking the eigenvalue stability condition in VAR model, the eigenvalues of the companion matrix lie inside the unit circle, and the real roots are far from 1. And the Jarque and Bera normality test results present statistics for equation jointly against the null hypothesis of normality. For the model, the results suggest normality. The joint test statistics of the White homoskedasticity test with the no cross terms is 76.40 , with a P-value of 0.03 , so the null hypothesis of non-heteroskedasticity at a $1 \%$ confidence level is not rejected. Hence, the model passes all the tests successfully and the residuals are Gaussian white noise. Finally, auto-regressive conditional heteroskedasticity (ARCH) effects shows that the absence of this problem in the analysis under study.

\section{Conclusion}

This paper analyses the possible relationship among the electricity demand, GDP and employment in Shandong. First we test the unit root in level and then in $1^{\text {st }}$ difference and the results show that variables are stationary in the $1^{\text {st }}$ difference. The cointegration equation coefficients show that if there is 1 per cent change of LNGDP in lag order 1, there is a 0.005 per cent change in LNEED. And that if there is a 1 per cent change in LNEEP in lag order 1 , there is a 0.72 per cent change in LNEED. So that we can know the LNEEP has much bigger impacts upon the LNEED. This result shows that there is a positive correlation among electricity demand, GDP and employment.

Granger causality test indicates that LNGDP does not Granger cause LNEED, but LNEED does Granger cause LNGDP. As to LNEEP and LNEED, LNEEP does not Granger cause LNEED, but LNEED does Granger cause LNEEP. This means that there is a one-way Granger causal relationship both from LNEED to LNGDP and from LNEED to LNEEP. As to LNEEP and LNGDP, we can see from the results that there is a two-way Granger causal relationship existing. That is, LNEEP Granger causes LNGDP and LNGDP Granger causes LNEEP, too.

Since that Shandong GDP growth can be explained by the electricity demand increase and the increased number of people employed, policies encouraging electricity demand increase and employment can be issued to help push further economic development in Shandong province.

\section{Acknowledgments}

Shandong social science planning research project: Research on dynamic collaborative development of Shandong manufacturing industry and producer services industry (19CDNJ31).

\section{References}

1. Magazzino, C. (2014). Electricity demand, gdp and employment: evidence from Italy. Frontiers in Energy, 8(1), 31-40.

2. John Garen, Christopher Jepsen, \& James Saunoris. (2011). The relationship between electricity prices and electricity demand, economic growth, and employment. Economics in Power Energy, 10(2), 56-78

3. Jiang-Hong, N., \& Wei-Min, Z. (2008). Research on introducing electricity demand elasticity into electricity market. Power System Technology, 32(11), 84-89.

4. MendezCarrillo, Ericka Cecilia. (2014). A long- and short-run analysis of electricity demand in ciudad juarez. Dissertations \& Theses - Gradworks.

5. Svoboda, P., \& Brcak, J. (2013). Electricity consumption demand model in Czech households. International Advances in Economic Research, 19(1), 63-64.

6. Holland, S. P. \& Mansur, E. T. (2008). Impacts of electricity demand variance. Review of Economics and Stats, 90(3), pp.550-561.

7. Aqeel Ahmed Bazmi, Meysam Davoody, \& Gholamreza Zahedi. (2012). Electricity Demand Estimation Using an Adaptive Neuro-Fuzzy Network: A Case Study from the State of Johor, Malaysia. International Conference on Energy and Environmental - ICEE 2012. 